\title{
Study on extraction process of alcohol-soluble ingredients from Hellgrammites(Megaloptera: Corydalidae)
}

\author{
Daifang Zhang ${ }^{1}$, Ming Pan', Yuyun Chen ${ }^{1, *}$ \\ ${ }^{1}$ Department of Chemical Engineering, Sichuan University of Science \& Engineering, \\ Zigong643000, Sichuan, China \\ ${ }^{2}$ School of Bioengineering, Sichuan University of Science \& Engineering, Zigong643000, Sichuan, \\ China \\ *Corresponding author1612551648@qq.com
}

Keywords: Hellgrammites, Alcohol extract, Fatty acid, Trace elements

\begin{abstract}
Study the alcohol soluble ingredient extraction process of Hellgrammites and the significance of whether it can be exploited the medicinal liquor. Using the crude product of Hellgrammites, the impact factors are the ethanol concentration, the extracting time and the ratio of the material liquid. These three factors are in the three level to do the orthogonal experiments. Using the alcohol extract of Hellgrammites as the sample, the meteorological mass spectrometry and the inductively coupled mass spectrometry, qualitatively detect the composition of fatty acid and quantitatively detect the content of trace elements of $\mathrm{Zn}$ and $\mathrm{Mn}$. The best extraction technology conditions are: the ethanol concentration is 60 percent and the extraction time is 2.5 hours. The ratio of material liquid is one contrasting fifty. The compositions of fatty acid are: palmitic acid, stearic acid, oleic acid, linoleic acid, gamma linolenic acid, arachidonic acid, and eicosapentaenoic acid. The trace elements of $\mathrm{Zn}$ and $\mathrm{Mn}$ : the trace elements in the crude products are 140.15ug per gram and 67.69ug per gram, the trace elements in the alcohol extract are 48.87ug per gram and 11.58ug per gram. Experiments show that the alcohol process is reasonable, stable and feasible. Alcohol extraction of fatty acid and the trace elements of $\mathrm{Zn}$ and Mn have high contents. It can be further developed for efficacy to medicinal liquor products.
\end{abstract}

\section{Introduction}

Hellgrammites, the larval form of the dobsonfly, are a completely abnormal insect, scientific name: Corydalus cornutus (Linnaeus), belonging to the family Megaloptera. The insects are distributed in the Americas, Asia, and South Africa. It is a widely distributed insect in China ${ }^{[1]}$. The hellgrammite insect is a common name for the larvae of the genus Polygonaceae, and it is a completely metamorphic insect ${ }^{[2]}$. The hellgrammite insect is rich in protein and various mineral elements, including protein content of $75.5 \%$ and vitamin B2 content of $3.46 \mathrm{mg} / 100 \mathrm{~g}^{[3]}$. Hellgrammite are not only a kind of food, but also have a good effect in treating the elderly with frequent urination and urinary bed in children ${ }^{[4,5]}$.

Chinese medicine believes that: hellgrammites have the effect of tonifying qi and kidney, suppressing deficiency and solidifying, nourishing and strengthening, and can be called medicine 
and food, and people use sand reptiles to soak wine or match hellgrammites with three After the seventh class of soaking wine to treat rheumatism ${ }^{[6]}$, it has the reputation of "animal ginseng". In recent years, with the in-depth study of hellgrammites, Yang DM et al ${ }^{7,8]}$ studied the fertility and growth of Drosophila extracts. The results showed that the extracts of hellgrammites can significantly increase the fruit fly progeny. The number increases the fecundity; it can significantly increase the body weight of Drosophila adults and promote their growth and development. China has abundant resources for hellgrammites and has formed artificial breeding industry. A number of related patents have been reported.

At present, in addition to the consumption of restaurants, there are no hellgrammite products on the market, and its development and utilization is still in a very primitive stage, and the market space is very large. Therefore, the subject is based on the direction of hellgrammites and alcohol extracts. The study of fatty acids, determination of the content of fatty acids, trace elements $\mathrm{Zn}$ and $\mathrm{Mn}$ in alcohol extracts, clear the extraction process, and develop its potential medicinal value, is of great significance for the effective and rational use of hellgrammite resources, The hellgrammites product "hellgrammites efficacy medicinal liquor" has a positive effect.

\section{Materials and methods}

\subsection{Instruments}

Pharmaceutical Ultrasound Processor (Model: FS-150N, Shanghai Shengsen Ultrasonic Instrument Co.), Freeze Dryer (Model: BT-85, Millrock Technology Company), Trace-1310 Gas Chromatograph (American Thermo Scientific), PSQ-8000 Mass Spectrometer (American Thermo Scientific), DB Digital Display Electrothermal Plate (Beijing Yongguangming Medical Instrument Co., Ltd.), 7700X Inductively Coupled Plasma Mass Spectrometry Instrument (Agilent, USA).

\subsection{Materials}

Fresh hellgrammites(HGM) were purchased from local farmers’ markets in Sichuan Panzhihua, China. KOH, methanol, absolute ethanol, concentrated nitric acid, hydrogen peroxide( Sichuan Kelun Pharmaceutical Co).

\subsection{Methods}

\subsubsection{Extraction of alcohol-soluble substances from hellgrammites}

Fresh hellgrammites were purchased from local farmers' markets in Sichuan Panzhihua, China. Remove head, tail and viscera, freeze dry insect, get dry ingredients, crush and reserve. The dry powder of hellgrammite was accurately weighed $2 \mathrm{~g}$, extracted by condensation and reflux with a certain amount of ethanol, and recovered by vacuum rotary evaporation. The alcohol-soluble substances in the evaporator were dried repeatedly until the constant weight (the difference between the two weights was less than $2 \mathrm{mg}$ ). The crude fat mass fraction of sample is calculated as follows 2-1:

$$
\mathrm{X}=\left(\mathrm{m}_{2}-\mathrm{m}_{1}\right) / \mathrm{m} \times 100 \%
$$

$\mathrm{X} \longrightarrow$ Crude fat mass fraction, $\%$

m—Sample quality, g

$\mathrm{m}_{1}$ - evaporating dish quality, $\mathrm{g}$

$\mathrm{m}_{2} \longrightarrow$ Crude fat and evaporating dish quality, g 


\subsubsection{Orthogonal design experiment of alcohol extract from hellgrammites}

In the pre-experiment, considering the influence of the ratio of material to liquid, the extraction time and the concentration of ethanol on the yield of ethanol extract, the orthogonal experimental factors and levels were determined on the above three factors. The effects of various factors on fatty acid, $\mathrm{Zn}$ and $\mathrm{Mn}$ in ethanol extract were studied by L9(34) orthogonal experiment, and the optimum extraction conditions were selected.

Tab2-3 Design of the orthogonal of alcohol extracts of hellgrammites

\begin{tabular}{cccc}
\hline \multicolumn{1}{c}{ Factors } & $\begin{array}{c}\text { A } \\
\text { Ethanol concentration } \\
\text { level }\end{array}$ & $\begin{array}{c}\text { B } \\
\text { Extraction time } /\end{array}$ & $\begin{array}{c}\mathrm{C} \\
\text { Ratio of material to } \\
\text { liquid }\end{array}$ \\
\hline 1 & 50 & 1.5 & $1: 50$ \\
2 & 60 & 2 & $1: 60$ \\
3 & 70 & 2.5 & $1: 70$ \\
\hline
\end{tabular}

\subsubsection{Single factor experiment}

Consider the ratio of material to liquid (1:40, 1:50, 1:60, 1:70), extraction time $(1,1.5,2,2.5)$, ethanol concentration $(50 \%, 60 \%, 70 \%, 80 \%)$ The effect of three single factors on the yield of alcohol extracts. The filtrate was extracted by the orthogonal test of ethanol extraction. When other conditions were unchanged, the effect of a single factor on the yield of the medicinal ingredients of the alcohol extract of the hellgrammite was studied.

\subsubsection{Hellgrammite extracts of GC-MS and Zn, Mn trace elements ICP-MS}

\subsubsection{Sample Pretreatment}

The room temperature methyl esterification method ${ }^{[9]}$ qualitative analysis of fatty acids, take $0.1 \mathrm{~g}$ of the larvae alcohol extract sample into a test tube, add 1:1 petroleum ether - benzene solution $2 \mathrm{ml}$, the sample is fully dissolved, then add $0.4 \mathrm{~mol} 2 \mathrm{ml}$ of $\mathrm{KOH}$-methanol solution was allowed to stand at room temperature for $10 \mathrm{~min}$, and then purified water was added to stand for stratification, and the supernatant was taken for analysis. Pretreatment of samples by wet nitration method ${ }^{\text {[10] }}$ quantitative analysis of $\mathrm{Zn}, \mathrm{Mn}$ trace elements. Separately weighed $0.1 \mathrm{~g}$ of crude sand worm, $0.05 \mathrm{~g}$ and $0.1 \mathrm{~g}$ of sphagnum alcohol extract, $0.05 \mathrm{~g}$, placed in a small beaker that has been washed and dried, added 1 2ml of purified water, infiltrated, added $5 \mathrm{ml}$ thick Nitric acid, $2 \mathrm{ml}$ hydrogen peroxide, shake well, placed on a digital heating plate at $200^{\circ} \mathrm{C}$ for $10 \sim 20 \mathrm{~min}$, until the cup is nitrated to clarification, add $2 \%$ nitric acid to $100 \mathrm{ml}$ spare.

\subsubsection{Gas chromatographic conditions}

Column: TG-5MS capillary column $(30 \mathrm{~m} \times 25 \mathrm{um} \times 0.25 \mathrm{um})$; inlet temperature: $260^{\circ} \mathrm{C}$; split ratio: $30: 1$; carrier gas: high purity nitrogen, flow rate of $1.0 \mathrm{ml} / \mathrm{min}$; initial temperature $120^{\circ} \mathrm{C}$, kept for 1 min, raised to $230^{\circ} \mathrm{C}$ at a heating rate of $4^{\circ} \mathrm{C} / \mathrm{min}$, held for $25 \mathrm{~min}$.

The fatty acid methyl ester is separated by a gas chromatography capillary column to obtain a total ion chromatogram of the mass spectrum. The fatty acid composition was determined according to the NIST mass spectrometry library and the retention time of the larvae alcohol extract sample, 
and the relative content was calculated by the area normalization method.

\subsubsection{Mass spectrometry conditions}

EI source, electron energy $70 \mathrm{ev}$; ion source temperature: $230^{\circ} \mathrm{C}$; quadrupole temperature: $280^{\circ} \mathrm{C}$; transmission line temperature: $230^{\circ} \mathrm{C}$; mass range: $40 \sim 400 \mathrm{amu}$; solvent delay: $10 \mathrm{~min}$.

\subsection{Statistical analysis}

The variance analysis was performed on the orthogonal test results using SPSS 17.0 software. $P$ values $<0.05$ were considered significant.

\section{Results}

\subsection{Single factor experiment results of alcohol extraction from hellgrammites}

\subsubsection{Effect of material to liquid ratio on crude fat content of alcohol extract}

Under the condition of 50\% alcohol concentration and $1.5 \mathrm{~h}$ extraction time, the crude fat content of ethanol extract increased obviously from 1:40 to 1:60, and the crude fat content of ethanol extract decreased obviously at 1:70. It shows that the crude fat content of alcohol extract has been basically dissolved in 1:60, and the solvent is added to cause waste. Material 1:60 is the best. The results are shown in Figure1.

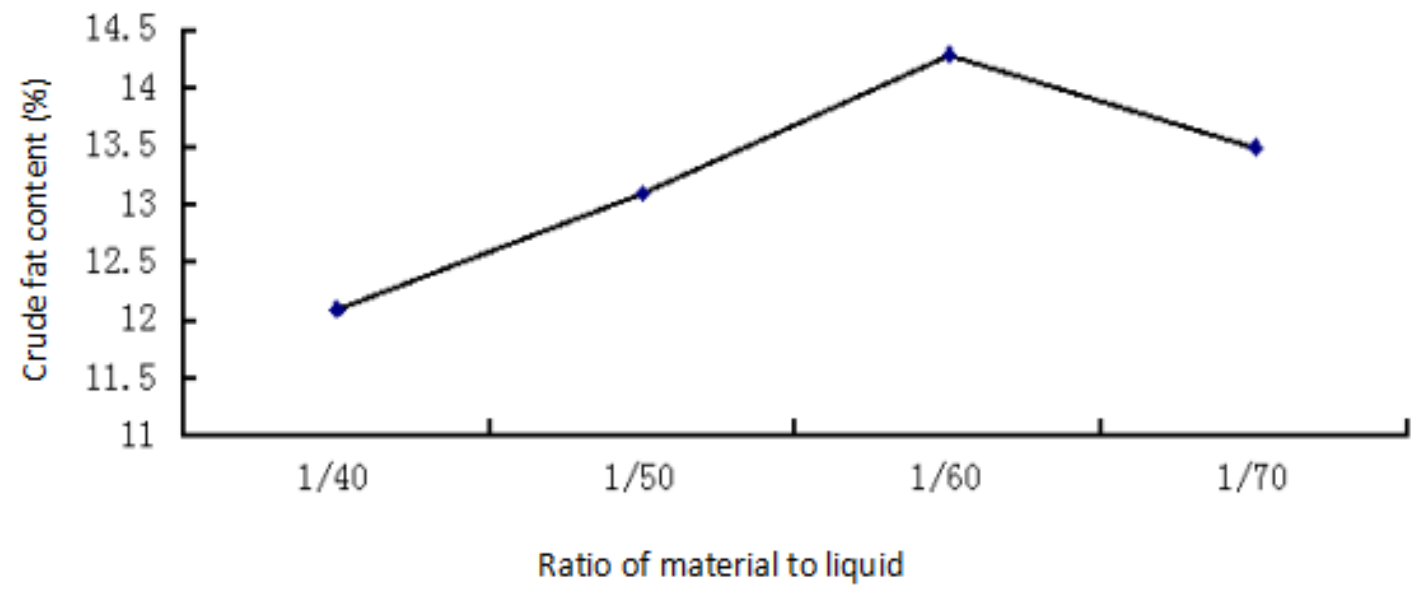

Fig.1 Effect of solid-liquid ratio on the content of crude fat of alcohol extracts

\subsubsection{Effect of extraction time on crude fat content of alcohol extract}

Under the condition of 1:60 ratio of material to liquid and 50\% alcohol concentration, different extraction time was selected. It can be seen from Figure2 that the effect of extraction time on the crude fat content of alcohol extracts is increasing, and the extraction time is $2 \mathrm{~h}$ and $2.5 \mathrm{~h}$. The content is relatively high, but the content growth is obviously slow after $2 \mathrm{~h}$. Considering the improvement of efficiency and cost saving, the extraction time is $2 \mathrm{~h}$ as the best extraction time. 


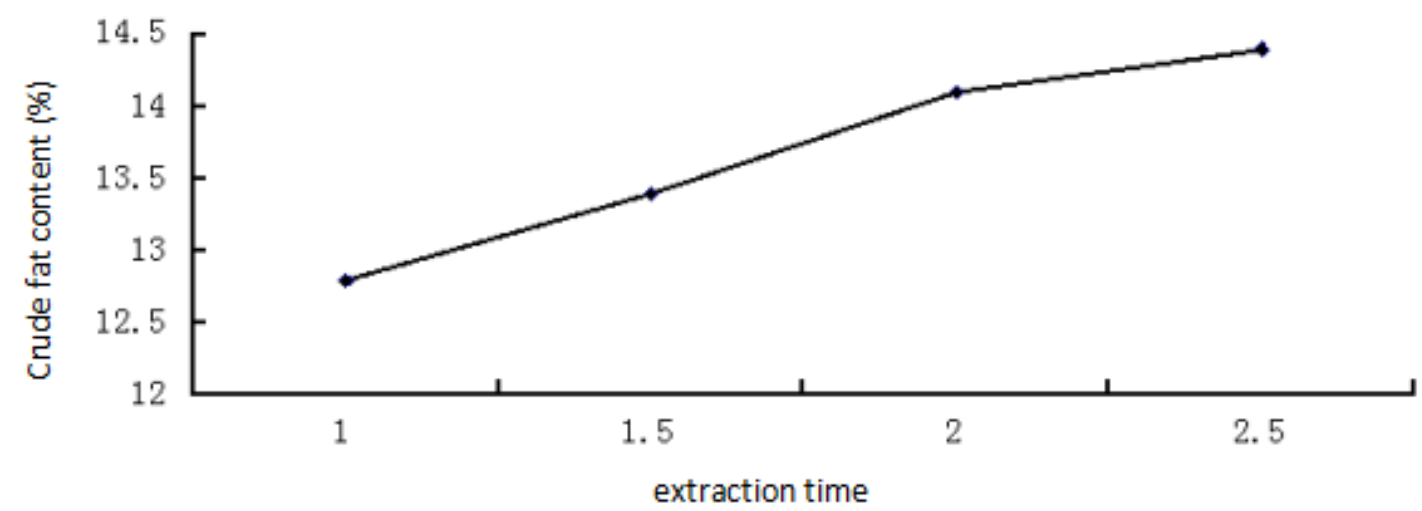

Fig. 2 Effect of extraction time on the content of crude fat of alcohol extracts

\subsubsection{Effect of ethanol concentration on the content of crude fat of alcohol extracts}

The results are shown in Figure3. When the ratio of material to liquid is 1:60 and the extraction time is 2 hours, different alcohol concentration is selected. From Figure 2-3, it can be seen that the alcohol concentration has a great influence on the crude fat content. When the concentration of ethanol reaches $60 \%$, the crude fat content reaches $21.8 \%$, which indicates that the dissolution content of crude fat is the highest when the concentration of ethanol is $60 \%$. Ethanol concentration of $60 \%$ is the best.

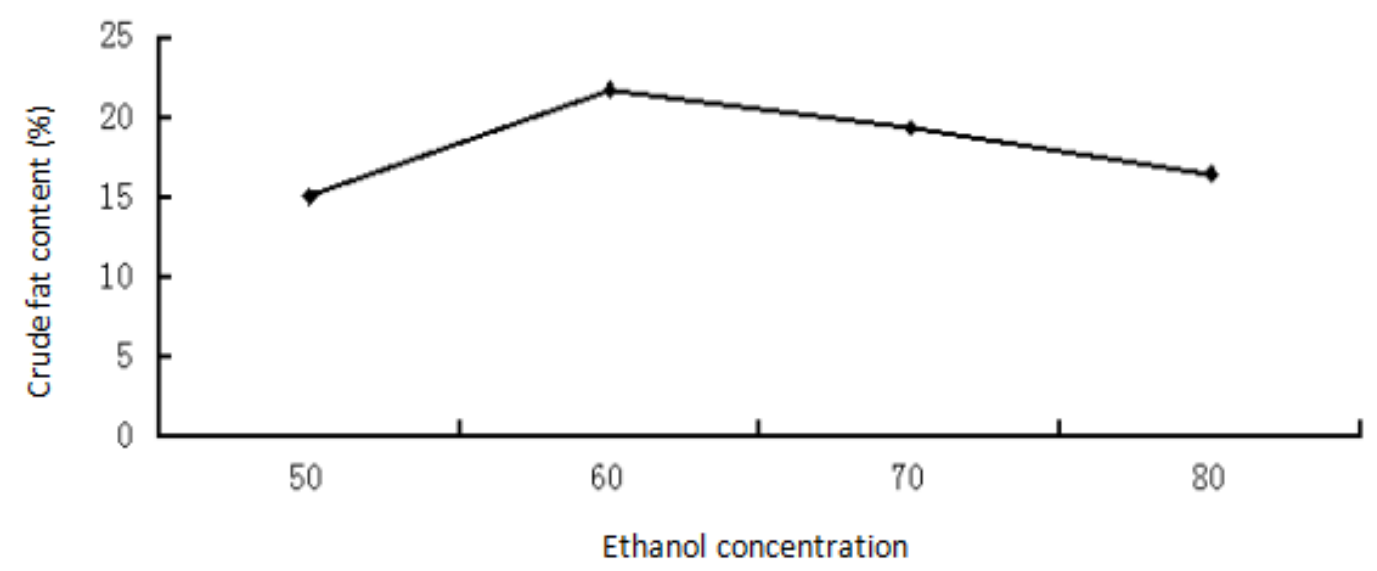

Fig.3 Effect of alcohol concentration on the content of crude fat of alcohol extracts

\subsection{Orthogonal experimental data processing of crude fat of hellgrammites}

According to the principle of statistics, Table1 shows that the greater the $\mathrm{R}$ value, the greater the effect of this factor on the experiment, $\mathrm{RA}>\mathrm{RC}>\mathrm{RB}$, so the primary and secondary factors affecting the crude fat yield of hellgrammite are $\mathrm{A}>\mathrm{C}>\mathrm{B}$. 
Table 1 The result of the orthogonal test

\begin{tabular}{ccccc}
\hline Factors & A & B & C & $\begin{array}{c}\text { Crude fat content } \\
(\%)\end{array}$ \\
\hline Test number & $1: 50$ & 1.5 & 50 & 12.01 \\
2 & $1: 50$ & 2 & 60 & 13.32 \\
3 & $1: 50$ & 2.5 & 70 & 10.46 \\
4 & $1: 60$ & 1.5 & 60 & 16.12 \\
5 & $1: 60$ & 2 & 70 & 16.02 \\
6 & $1: 60$ & 2.5 & 50 & 22.18 \\
7 & $1: 70$ & 1.5 & 70 & 17.58 \\
8 & $1: 70$ & 2 & 50 & 19.05 \\
9 & $1: 70$ & 2.5 & 60 & - \\
$\mathrm{K}_{1}$ & 35.79 & 45.71 & 53.24 & - \\
$\mathrm{K}_{2}$ & 54.32 & 48.39 & 46.28 & - \\
$\mathrm{K}_{3}$ & 53.47 & 49.48 & 44.06 & - \\
$\mathrm{R}$ & 18.53 & 3.77 & 9.18 & \\
\hline
\end{tabular}

Table 1 shows that $\mathrm{K} 2$ is the most important factor in factor $\mathrm{A}, \mathrm{K} 3$ is the most important factor in factor $\mathrm{B}, \mathrm{K} 1$ is the most important factor in factor $\mathrm{C}$, and A2B3C1 is the best matching level for extracting crude fat from hellgrammites. The yield of crude fat reached $22.18 \%$ at the optimum combination.

Table 2 ANOVA of the content of crude fat of alcohol extracts

\begin{tabular}{ccccccc}
\hline Factors & $\begin{array}{c}\text { Sum of } \\
\text { squares of } \\
\text { deviations }\end{array}$ & Freedom & $\begin{array}{c}\text { mean } \\
\text { square }\end{array}$ & $\mathrm{F}$ & $\mathrm{F}_{\mathrm{a}}$ & Saliency \\
\hline $\mathrm{A}$ & 73.54 & 2 & 36.77 & 23.87 & 19.00 & $\mathrm{P}<0.05$ \\
$\mathrm{~B}$ & 3.08 & 2 & 1.54 & 1 & 19.00 & - \\
$\mathrm{C}$ & 33.62 & 2 & 16.81 & 10.81 & 19.00 & - \\
Error & 3.08 & 2 & 1.54 & - & - & - \\
\hline
\end{tabular}

$\mathrm{F}_{0.05(2,2)}=19.00$

According to Table 2, on the basis of orthogonal test, the ratio of ethanol extract to liquid is significant, which shows that the ratio of extract to liquid has the greatest influence on the extraction rate of crude fat of hellgrammites. Through orthogonal experiment, the optimum conditions for extracting crude fat from hellgrammites are as follows: alcohol concentration $60 \%$, extraction time $2.5 \mathrm{~h}$, material-liquid ratio 1:50. That is, $\mathrm{A}_{2} \mathrm{~B}_{3} \mathrm{C}_{1}$. This is similar to the results of $\mathrm{Li}$ $\mathrm{SM}^{[42]}$ in the extraction of insect oil, fatty acid composition analysis and purification of alpha-linolenic acid.

\subsection{Verification of orthogonal experiment results}

Under the optimum conditions, the crude oil content of hellgrammites was $21.6 \%, 21.2 \%$, $21.1 \%$ and $21.3 \%$, respectively. The results showed that the above methods were feasible and the crude fat content was stable. 


\subsection{Analysis of fatty acid composition of oil extracts from hellgrammites by GC-MS}

Table3 The fatty acid content of hellgrammites (\% of total fatty acids)

\begin{tabular}{|c|c|}
\hline component & Content(\%) \\
\hline Palmitic oleic acid & 14.1 \\
\hline Palmitic acid & 17.2 \\
\hline stearic acid & 6.9 \\
\hline oleic acid & 24.6 \\
\hline linoleic acid & 5.7 \\
\hline Gamma linolenic acid & 0.81 \\
\hline Arachidonic acid four & 2.8 \\
\hline Twenty carbon five enoic acid & 21.5 \\
\hline Monounsaturated fatty acids & 48 \\
\hline Polyunsaturated fatty acids & 33 \\
\hline
\end{tabular}

According to Table 3 , the fatty acids of hellgrammites are mainly palmitic acid, oleic acid (C18:1n-9), eicosapentaenoic acid (EPA), and the content of stearic acid is low (C18:0). Among them, reptiles are also rich in arachidonic acid, eicosapentaenoic acid (EPA), which plays an important role in human nutrition, development, health and the content of EPA is as high as $21.5 \%$.

\subsection{Determination of hellgrammites $\mathrm{Zn}$ and $\mathrm{Mn}$ in alcohol extract by ICP-MS}

The results of $\mathrm{Zn}$ and Mn content are shown in table 4.

Table 4 Hellgrammites Zn, Mn trace element detection results

\begin{tabular}{|c|c|c|}
\hline Element & $\begin{array}{l}\text { Coarse hellgrammites } \\
\text { ug/g }\end{array}$ & $\begin{array}{c}\text { Alcohol extract of hellgrammites } \\
\text { ug/g }\end{array}$ \\
\hline $\mathrm{Zn}$ & 140 & 48.8 \\
\hline Mn & 67.6 & 11.6 \\
\hline
\end{tabular}

\section{Discussion}

As a kind of medicine and food insect, hellgrammite has the effect of invigorating lung, strengthening kidney yang, treating phlegm, asthma and cough, and treating deficiency of deficiency and strain ${ }^{[2]}$. Myrica rubra et al. have proved that the extract of hellgrammites can improve the fecundity of Drosophila melanogaster and promote its growth and development.

Fat is one of the important nutrients to maintain human health. The performance and function of fat mainly depend on fatty acid ${ }^{[12]}$. Most unsaturated fatty acids have many physiological functions, such as anti-tumor, improving immunity and treating schizophrenia ${ }^{[13-15]}$. They are also beneficial to reducing blood sugar, regulating blood lipids, reducing cholesterol content and protecting the heart. They also have the effect of enhancing memory ${ }^{[7,16-18]}$. They are essential 
nutrients for human body. Hellgrammite oil can not only maintain relatively low stearic acid, but also relatively high palmitic acid and oleic acid, and hellgrammites also rich in EPA, its content is as high as $21.5 \%$. Zhu $\mathrm{LY}^{[19]}$ and others found that EPA is a very important resource, can prevent cardiovascular diseases, and has anti-cancer, anti-inflammatory effects, promote the development of the nervous system and visual system.

In addition, the content of $\mathrm{Zn}$, Mn hellgrammites can be used as a quality standard of kidney tonic drugs, lack of zinc, manganese will lead to endocrine dysfunction or gland atrophy, the occurrence of kidney reproductive development pathological changes. According to Xu NC ${ }^{[20]}$, it is pointed out that hellgrammites, such as zinc and manganese, which are closely related to the pharmacodynamics. It can be used as reliable reference for screening kidney tonics for the treatment of kidney deficiency. The results showed that the contents of $\mathrm{Zn}$ and $\mathrm{Mn}$ were $140.15 \mathrm{ug} / \mathrm{g}$ and $67.69 \mathrm{ug} / \mathrm{g}$, respectively, and the contents of $\mathrm{Zn}$ and $\mathrm{Mn}$ were $48.87 \mathrm{ug} / \mathrm{g}$ and $11.58 \mathrm{ug} / \mathrm{g}$, respectively. It can be seen that hellgrammites medicinal liquor is a product worthy of development.

\section{Conclusions}

In a word, through orthogonal design experiment, the optimum process of ethanol extract was determined. The ethanol concentration was $60 \%$, the ratio of material to liquid was $1: 60$, the extraction time was $2.5 \mathrm{~h}$, the crude fat content was $22.18 \%$, the ethanol extraction process was reasonable and the yield was stable. The content of hellgrammites $\mathrm{Zn}$ and $\mathrm{Mn}$ in crude and ethanol extracts were $140.15 \mathrm{ug} / \mathrm{g}, 67.69 \mathrm{ug} / \mathrm{g}$ and $48.87 \mathrm{ug} / \mathrm{g}, 11.58 \mathrm{ug} / \mathrm{g}$, respectively. The prospect of utilization and development of hellgrammites was very wide. The development of hellgrammites medicinal liquor products was very promising. It will be very meaningful. Because there is no in-depth study on the hellgrammites in the literature at present, so there is no efficacy test. It is only a preliminary study on the preparation process of the ethanol extract for the detection of the ethanol extract of hellgrammites.

\section{Acknowledgements}

This work was supported by Sichuan Provincial Department of Education (17ZB0303), Graduate student innovation fund(y2017039) and this work was supported by Zigong City Science and Technology Innovation Seedling Project (2017cxm03), China.

\section{References}

[1] Jepson, J. E., and S. W. Heads. Fossil Megaloptera (Insecta: Neuropterida) from the Lower Cretaceous Crato Formation of Brazil. Zootaxa, 2016, 4098 (1):134-144.

[2] Cao, CQ. Situation of developing and utilizing crawling worm in china and species definition. Hubei Agricultural Sciences,2014, 21: 5061-5064.

[3] Li Yong, Wang Y, Zhao M, et al. Determination of nutrient composition of larvae of Macrobrachium orientalis [J]. Guizhou Agricultural Sciences, 2015, 43 (4): 196-197.

[4] Wang Fubin, Liu Yusheng. Development and utilization value of climbing bug ([J].) agricultural knowledge, 2009, (21): 38-39.

[5] Shi ZX. Survey of the field living environment of the special aquatic reptiles in Panxi [J]. Journal of Xichang University (Natural Science Edition), 2011, 25 (2): 46-50.

[6] Cheng XH. Multifunctional medicinal liquor and its preparation for rheumatic diseases[P]. Chinese patent: CN 101380345A, 2009-03-11.

[7] Yang, D., S. Tao, L. He, C. Wang and J. Li. Effects of protohermes grandis extract on reproductive capacity and life-span of drosophila melangogaste. Nat Prod Res Dev, 2012 24:366-369.

[8] Yang, D., J. Liang, P. Liao, C. Long, L. Luo and J. Li. Effects of protohermes grandis extract on growth and reproduction of mice. Nat Prod Res Dev, 2014, 26:1290-1293.

[9] Li HT, Zhang TS. Analysis of Mixed Fatty Acids by Gas Chromatography-Mass Spectrometry[J]. Leather Chemical 
Industry, 2003, 20 (6): 18-22.27.

[10] Shu GT, Qu HY, Zou HH,et al. Simultaneous determination of lead and mercury in cosmetics by leaching-nitration[J].Chinese Journal of Health Inspection, 1992, 2(5): 309-310.

[11] LI SM, LI ML. Extraction of various insect oils, analysis of fatty acids and separation and purification of alpha-linolenic acid[J]. Southwest University of Agriculture and Forestry, 2006, 6 (17): 20-21.

[12] Zhao Yuqi. Mass Spectrometric Analysis of Fatty Acid Methyl Ester[J]. National Center for Food Quality and Safety Supervision and Inspection, 2010, 29:132-135.

[13] LIU XY. A systematic taxonomic study of the Chinese panoptera (Insecta: Venipelata) [D]. Beijing: China Agricultural University, 2008.

[14] Value of climbing sand bug in Heuhui River, [EB/OL]. http//nc.mofcom.mofcom.gov.cn/articlep/px/njbk/tzty/tztylzjs/201212/1841259_1.html. 2012-12-05.

[15] Liu LR. A brief introduction to the resources and animals in Liangshan area and some suggestions on their protection and utilization[J]. Exploration of Nature, 1983 (4): 118-123.[8]

[16] Mossoba $M$ M, Mcdonald $R$ E, Roch $J$ A $G$, et al.. Spectral confirmation of trans monounsaturated $C<$ sub $>18</$ sub $>$ fatty acid positional isomers[J]. Journal of the American Oil Chemists Society, 1997, 74(2): 125-130.

[17] Patrikios I S, Patsalis P C. Monounsaturated fatty acid oligomerization is responsible for the agglutination activity of heated virgin olive oil[J]. Food Research International, 2003, 36(9-10): 985-990.

[18] Ovesen L, Leth T, Hansen K. Fatty acid composition and contents of trans monounsaturated fatty acids in frying fat and in margarines and shortenings maketed in Denmark[J]. Journal of the American Oil Chemists Society, 1998, 75(9): 1079-1083.

[19] Zhu LY, Zhang XC, Song XJ, et al. [J]. Marine Science, 2007, 31 (11): 78-79.

[20] Yu NC, Guan JH. Analysis and Study on Trace Elements and Therapeutic Effect of 8 Kidney-tonifying Herbs [J]. Shizhen Guoyao Research, 1997, 8 (6): 510-511. 